\title{
CREDIT, CRISIS AND CONTRACT
}

ENFORCEMENT: EVIDENCE FROM

2016 THE SPANISH LOAN MARKET

Juan S. Mora-Sanguinetti.

Marta Martinez-Maturte y Miguel Garcia-Posada

Documentos de Trabajo.

N. 1630

BANCO DE ESPANA

Eurosistema 
CREDIT, CRISIS AND CONTRACT ENFORCEMENT: EVIDENCE FROM

THE SPANISH LOAN MARKET 
CREDIT, CRISIS AND CONTRACT ENFORCEMENT: EVIDENCE FROM THE SPANISH LOAN MARKET ${ }^{*}$

Juan S. Mora-Sanguinetti, Marta Martínez-Matute and Miguel García-Posada ${ }^{(*)}$

BANCO DE ESPAÑA

${ }^{*}$ ) We are grateful to Ildefonso Villán Criado (CGPJ) for his advice in the use of the judicial performance data. We also thank Claire McHugh, Alice Guerra, Francisco Cabrillo and the participants at the VI Annual Conference of the Spanish Association of Law and Economics (AEDE) (Santander, 2015), the 2nd International Workshop on Economic Analysis of Litigation (Torino, 2015), the 32nd Annual Conference of the European Association of Law and Economics (EALE) (Vienna, 2015) and the Research seminar at the Banco de España for their comments and suggestions.

$\left.{ }^{* \star}\right)$ The three authors are members of the Research Department of the Banco de España-Eurosystem. Contact information: Juan S. Mora-Sanguinetti, Senior Economist and Lawyer. E-mail: juans.mora@bde.es. Tel.: (+34) 91338 5197. Fax: (+34) 91338 5486. Banco de España. Alcala 48, 28014, Madrid. The views expressed are those of the authors and should not be attributed to the Banco de España or the Eurosystem. 
The Working Paper Series seeks to disseminate original research in economics and finance. All papers have been anonymously refereed. By publishing these papers, the Banco de España aims to contribute to economic analysis and, in particular, to knowledge of the Spanish economy and its international environment.

The opinions and analyses in the Working Paper Series are the responsibility of the authors and, therefore, do not necessarily coincide with those of the Banco de España or the Eurosystem.

The Banco de España disseminates its main reports and most of its publications via the Internet at the following website: http://www.bde.es.

Reproduction for educational and non-commercial purposes is permitted provided that the source is acknowledged.

C BANCO DE ESPAÑA, Madrid, 2016

ISSN: 1579-8666 (on line) 


\section{Abstract}

A number of theoretical and empirical studies have shown that the development of credit markets is affected by the efficacy of enforcement institutions. A less explored question is how these institutions interact with turns in the economic cycle and the impact of different types of legal procedures on credit market performance. This paper fills these gaps by analysing how differences in the availability of credit and in non-performing loans ratios may be partially explained by regional variations in the quality of loan contract enforcement during recent periods of sustained growth (2001-2007) and recession (since 2008) in the Spanish economy. This research concludes that a rise in the clearance rate of executions (i.e. when a judge enforces the repayment of a debt) increases the ratio of total credit to GDP. However, the declaratory stage of proceedings (i.e. when a debt is first verified by a judge) does not seem to be statistically significant. A possible explanation of this finding is that, throughout the economic cycle, a significant proportion of the defaults declared are strategic (i.e. defaults by a solvent debtor). Furthermore, it is observed that, in regions where declaratory procedures are more efficient, less credit is declared as non-performing. The latter effect, however, is only observed after the onset of the "Great Recession" in 2008. This may be related to the increase in non-strategic defaults during a downturn.

Keywords: enforcement institutions, legal procedures, credit availability, non-performing loans ratio.

JEL classification: K41, E51, G2. 


\section{Resumen}

Numerosos estudios, tanto teóricos como empíricos, han puesto de manifiesto que la calidad del marco institucional tiene efectos sobre el funcionamiento del mercado de crédito. Una cuestión menos tratada por la literatura ha sido el efecto que tiene sobre el desarrollo de este mercado el diseño de los distintos procedimientos judiciales de un país y su interacción con el ciclo económico. Este artículo pretende cubrir ese espacio, mostrando cómo las diferencias provinciales en España en cuanto a la disponibilidad de crédito y la morosidad pueden ser explicadas en parte por diferencias en la eficacia del sistema judicial, ya sea en los períodos de crecimiento sostenido (2001-2007) como en los de recesión (desde 2008). Las conclusiones indican que una mejora de la eficacia de las ejecuciones judiciales (cuando un juez obliga forzosamente al pago de una deuda) incrementa la disponibilidad de crédito en España. Sin embargo, la eficacia de la fase declarativa del procedimiento (cuando la existencia de una deuda es verificada por un juez) no parece tener un efecto significativo sobre el crédito. Una posible explicación de esta observación es que una proporción importante de los impagos son estratégicos (es decir, realizados por deudores que son, en realidad, solventes). En paralelo, se observa una menor morosidad en las provincias en las que los procesos declarativos son más eficaces. Esta última observación es significativa solamente después del inicio de la Gran Recesión de 2008 y podría estar relacionada con el incremento de los impagos no estratégicos que se produce durante las crisis económicas.

Palabras clave: crédito, instituciones de ejecución, procesos judiciales, tasa de morosidad.

Códigos JEL: K41, E51, G2. 
The effect of recessions and expansions on the availability of credit is one of the most widely studied subjects in economics. In expansions, the supply of credit expands (due to lower credit risk and higher lender liquidity) and the demand for credit rises (due to more profitable investment opportunities). By contrast, in recessions, credit supply tightens and credit demand decreases ${ }^{1}$. However, the question of how enforcement institutions interact with changes in the economic cycle (and therefore how they affect economic variables) is a less explored issue.

During downturns economic agents have more difficulties in fulfilling their obligations and honoring their contracts and firms are more likely to experience financial distress. Therefore, litigation may increase during a crisis. Ginsburg and Hoetker (2006) and Palumbo et al. (2013) find evidence in this sense for some countries. A higher rate of litigation is related to higher court congestion and, therefore, should generate some negative economic impacts [see Palumbo et al. (2013) and OECD (2013) for a survey of the literature in this respect]. The overall effect will depend, however, on the capacity of the judiciary to adapt to changes in the rate of litigation and how, in general, enforcement institutions interact with other relevant economic variables in a crisis environment. In other words, the ultimate effect of changes in enforcement institutions on the credit market, as a result of changes in the economic cycle, deserves to be further explored, particularly where the "ecosystem" of procedures is complex, as is the case of Spain.

The literature has found that the quality of the enforcement institutions is a relevant determinant for the development of credit markets. This partially explains the restrictions experienced by some economic actors when accessing credit. Laeven and Majnoni (2005) show that improvements in judicial enforcement of debt contracts lower the costs of financial intermediation. Djankov et al. (2008) show that reductions in the length of time required to recover a debt promote the development of the debt markets. Exploiting the variation across countries, several papers (Bae and Goyal, 2009; Qian and Strahan, 2007, among others) document that better contract enforcement induces credit suppliers to increase loan size, lengthen loan maturity and reduce loan spreads. Jappelli et al. (2005) found that economic agents in Italian regions with more efficient judicial systems enjoy greater access to credit. A lower proportion of credit-constrained households was also observed in Italy in better performing judicial districts (Fabbri and Padula, 2004). There are also similar studies, with consistent results, for Brazil (Castelar Pinheiro and Cabral, 2009), Spain (Fabbri, 2010), Russia (Shvets, 2012) and India [Visaria (2009) and Chemin (2012)].

This paper intends, for the first time, to address the question of how institutions interact with expansions and recessions ${ }^{2}$ and to analyze the differential impact of declaratory procedures and executions in different parts of the economic cycle. In other words, the analysis of declaratory judgments and their executions allow us to study what stage is more important for business decisions and when: whether the time at which the existence of a debt is declared and

\footnotetext{
${ }^{1}$ There is a growing strand of empirical literature that aims to disentangle supply and demand factors of credit growth. See, inter alia, Gan (2007), Khwaya and Mian (2008), Jiménez et al. (2012), García-Posada and Marchetti (2015), Bentolila et al. (2015). On the procyclicality of credit growth and lending standards see, inter alia, Berger and Udell (2003), Lown and Morgan (2006) and Rodano et al. (2015).

${ }^{2}$ After a long period of expansion characterized by its high growth rates, the Spanish economy showed a negative quarterly GDP growth rate of $-1.4 \%$ in the fourth quarter of 2008. A deep recession began in that moment and lasted until 2013.
} 
acknowledged by a judge (declaratory stage) or the time at which the judge enforces its payment (execution). Hence, the use of "aggregate" measures of judicial efficacy, as done in the previous literature, may be incomplete.

It should be also noted that the analysis is carried out using real data ${ }^{3}$ (not estimates) of the performance of tribunals at the local level, following the reform of the Civil Procedure Law in 2000. Using "modern" data guarantees institutional stability and allows us to analyze how a judicial system governed by a modern set of procedural rules, characterized by a lower level of formalism (Mora-Sanguinetti, 2010), reacts to economic turns.

This framework of analysis and the research question seem to be relevant for the Spanish case. As it will be discussed in the next section, Spain seems to underperform, compared to other countries, with respect to the efficacy of its judicial system. The interaction of the Spanish judicial system and the crisis has yet to be analyzed. During the Spanish Great Recession ${ }^{4}$ (2008-2013), real GDP fell by more than an 8\%, the unemployment rate reached 26\% (coming from values below $10 \%$ during the preceding boom), credit to the non-financial sector dropped by more than $18 \%$ and real housing values fell by around $35 \% .{ }^{5}$ These developments led to a rise in defaults, in mortgage foreclosures -which increased by more than 55\%- and in the number of bankruptcy filings -which increased from approximately 1,000 cases a year to 10,000. To this it must be added that credit market conditions are particularly relevant for other issues of importance to the Spanish economy, such as the rates of entrepreneurship and growth of enterprises [Evans and Jovanovic (1989), Aghion et al. (2007), Samila and Sorenson (2011), Beck et al. (2008)]. It is also known that these variables are responsive to the functioning of the judicial system [Giacomelli and Menon (2012), Chemin (2009), García-Posada and MoraSanguinetti (2015a and 2015b $\left.{ }^{6}\right)$ ]. Both entry rates and the size of firms in Spain are lower than in other OECD countries (see the abovementioned references).

This paper analyzes the developments in the credit market and relates them to the efficacy of the judicial system in Spain at the local level over the period 2001-2012. Therefore, two periods in the economic cycle can be clearly distinguished: expansion until 2008 and the subsequent "Great Recession". The paper finds that higher judicial inefficacy reduces the availability of credit with respect to the region's GDP. Crucially, the importance of the impact depends on the type of procedure: only the efficacy of the "execution" that takes place after the "declaratory judgment" matters. Furthermore, it is observed that, in those regions where declaratory judgments are more efficient, a lower percentage of credit is declared non-performing. The latter effect, however, is only observed after the onset of the "Great Recession". In other words, the efficacy of the judicial system, for that particular case, has just produced differential effects since 2008. In summary, the differential impacts of the procedures (and their interaction with the business cycle) are an important aspect that has been traditionally overlooked.

The mechanism behind these results may be the following. Throughout the economic cycle, a relevant proportion of the defaults that take place are strategic (i.e., defaults by a solvent

\footnotetext{
${ }^{3}$ Previous studies on the issue are usually based on estimations of judicial efficacy (thus, not real efficacy data): for instance the indicator proposed by Djankov et al. (2003) which inspired the Doing Business (DB) project (contract enforcement indicator) or the DB data directly. Measures which proxy the length of the procedure used in other studies [such as Fabbri (2010)] are again estimations (in that case, at the region level).

${ }^{4}$ For an analysis of the Spanish "Great Recession" see Jimeno and Santos (2014).

${ }^{5}$ Data obtained from official sources: Spanish National Statistics Institute (INE), Banco de España - Eurosystem and the Ministry of Housing.

${ }^{6}$ This study shows that more effective courts, measured using real performance data at the local level, seem to promote higher entry rates of entrepreneurs in Spain.
} 
debtor). In such a situation, lenders rely on the efficacy of execution procedures (for instance, seizure of loan collateral by a court) to recover loans, and they are only willing to provide credit ex-ante if those procedures deter moral hazard and strategic defaults. This implies a positive relation between the clearance rate at the execution stage (i.e., when a judge forces the repayment of a debt) and credit availability. By contrast, non-strategic defaults (i.e., defaults caused by the debtor's inability to honor his debts) are much more frequent during recessions than strategic defaults, because borrowers' cash flows and collateral values are very low. In that case, what matters is the judicial efficacy at the declaration stage (i.e., when the existence of a debt is declared and acknowledged by a judge), as debtors do not voluntarily default on their obligations, implying that they do not need to be forced to repay their debts. Once there is a declarative judgment against them, they will promptly attempt to repay, especially as Spanish law establishes penalties for delayed payment (i.e. the debt accrues interest if not immediately paid after the judgment), which discourages the debtor from delaying payment and reduces the need for an enforcement procedure after the declaratory judgment. This implies a negative relation between the clearance rate of declaratory judgments and the non-performing loan ratio for the crisis period. The remainder of this paper is organized as follows. Section 2 explains the structure of the judicial system in Spain, how the efficacy measures used in the study have been built and how they have evolved over our period of analysis. Section 3 explains how credit availability has been measured and discusses the controls introduced in our estimations. Section 4 presents our identification strategy and Section 5 shows the main results. Finally, Section 6 sets out some conclusions.

\section{Developments in the efficacy of justice in Spain from expansion to recession}

The study of the effects of the judicial system in the credit market seems especially relevant to Spain, where judicial efficacy is lower than in other comparable economies (García-Posada and Mora-Sanguinetti, 2015b). According to the latest analyses for the OECD countries (Palumbo et al., 2013) the Spanish judicial system would be slower resolving a civil dispute compared to the average common law or German law country. ${ }^{7}$ These findings are consistent with other international reports such as the World Bank's "Doing Business" series.

The analysis of the effects of enforcement institutions in Spain is facilitated by the availability of a large database on the functioning of the judiciary. The database, provided by the General Council of the Judiciary (hereinafter CGPJ), reports on the workload of the courts in all Spanish jurisdictions ${ }^{8}$ broken down by types of procedures. The information contained in the database is actual operating data and therefore it is not based on estimates of the duration of procedures. This is a clear advantage compared to other databases. A deeper analysis of this database (and its limitations for the analysis) can be found in Mora-Sanguinetti (2012) or Garcia-Posada and Mora-Sanguinetti (2015a).

A conflict concerning the default on a loan by a borrower (either a company or a citizen that has contracted a loan) is channeled through the civil jurisdiction in the Spanish judicial system. The civil jurisdiction, in fact, is usually involved in any conflicts of a private nature. An outline of the civil jurisdiction procedures is shown in Figure 1.

\footnotetext{
${ }^{7}$ More specifically, Spain is ranked 26 out of a total of 35 legal systems in terms of its agility to resolve disputes before the first instance courts. Spain obtains a better result than the "average" civil law country, but worse than the average Common Law or German Law countries.

${ }^{8}$ The Spanish judicial system is divided into four different jurisdictions (civil, labour, administrative and criminal), served by specialized judges. We must emphasize that in Spain, civil and labour jurisdictions are separated.
} 
The creditor (e.g. a bank) that suffers a default by a debtor must address the "courts of first instance" (or the "courts of first instance and instruction" if the claim is filed in a small town) and has several procedures available depending on the amount of the debt: the ordinary judgment (for debts greater than 6000 euros), the verbal judgment (for debts less than 6000 euros), a payment procedure (monitorio) or a 'bills of exchange and cheques' procedure. ${ }^{9}$

All of these are declarative procedures, i.e., the civil judge verifies (declares) that the debt exists and that, indeed, it has not been paid. Therefore, the conflict should end there and the debtor, in compliance with the judgment, should repay the debt.

However, debtors do not always pay the debt immediately after a declaratory judgment has taken place. There are two types of debtors: strategic debtors (solvent debtors) and non-strategic debtors (those who actually do not return the debt because their financial situation does not allow them to pay at that time). The strategic debtor may have incentives to delay the full repayment of debt in order to have more cash in the short term. To restrain such behavior, the Spanish law ${ }^{10}$ establishes penalties for delayed payment (i.e., the debt accrues interest if not immediately paid after the judgment). Obviously, there are other non-pecuniary factors such as reputation that may deter strategic behaviour. If the debtor decides, after all, not to repay the loan even after the declaratory judgment, a second procedure, an execution, could take place. In the execution stage, the civil judge forcibly compels the debtor to pay (for example, the judge may take the money from the bank accounts of the debtor).

In summary, we should not just rely on aggregate measures of judicial efficacy and we should distinguish between the two stages of the procedures (the declaration, i.e., when a debt is verified by a judge, and the execution, i.e., when a judge enforces the repayment of a debt). ${ }^{11}$

In our analysis, we focus on the declaratory ordinary procedures (that would normally be used in conflicts in which the debt is higher than 6000 euros)..$^{12}$ However, we should recall that Figure 1 is just a simplification. The ordinary judgment presented there is itself a set of procedures (preliminary hearing, examination of evidence, etc.) that ends with a sentence issued by a judge. For further information on the steps needed to arrive to a judgment, see MoraSanguinetti (2010). $\cdot^{13}$

\footnotetext{
${ }^{9} \mathrm{~A}$ 'bills of exchange and cheques' procedure takes place if a bill of exchange, a cheque or a promissory note is presented (Article 819 of the Civil Procedural Law). A 'payment procedure' takes place if someone seeking payment of a monetary debt, presents in the court evidence of the debt in the form of a document, an invoice and other similar options. The debt may be of any amount and must be liquid, determined, due and payable (Article 812 of the Civil Procedural Law).

${ }^{10}$ Article 576 of the Civil Procedural Law.

${ }^{11}$ Interestingly, in their study of the impact of judicial efficacy on firm size and growth, García-Posada and MoraSanguinetti (2015a) find that the procedures at the declaratory stage are the ones that have an impact on those variables. This is an illustration of how complex is the issue of judicial efficacy and economic performance and how much further research is required in the area.

${ }^{12}$ We have also analyzed the effect of another procedure, the verbal judgment, on the availability of credit and we have obtained similar results.

${ }^{13}$ In the ordinary procedure, before reaching the judgment (declaration), the parties, under the supervision of the judge, go through many formal steps. Following the demand by the creditor and the defense by the debtor, there is a preliminary hearing of the parties (Article 414 of the Civil Procedural Law, CPL). Subsequently, the trial itself includes the examination of evidence, the formulation of conclusions by the parties and other reports (Article 433 of the CPL). While the parties cannot choose the particular judge that will resolve their case, they are obliged to go through all the parts of the procedure in the court assigned (for example, the court of first instance number 92 of Madrid or court of first instance number 31 of Barcelona). Citizens and businesses cannot intervene in the structure of the procedures (which are regulated and fixed by the CPL).
} 
As previously pointed out, our period of analysis begins in 2001. It is when the new Civil Procedure Law (CPL) of 2000 came into force. ${ }^{14}$ Using data that reflect the enforcement procedure under the new CPL guarantees institutional stability in the whole period of analysis (civil proceedings before and after 2001 are not strictly comparable). This allows us to study the effects on the credit market of a procedural law which has been deemed as modern and with a low level of formalism compared to the old CPL (Mora-Sanguinetti, 2010). Our period of analysis ends in 2012 because there is no disaggregated data (at the province level) on some other variables important for the analysis.

Figure 1: Civil jurisdiction scheme

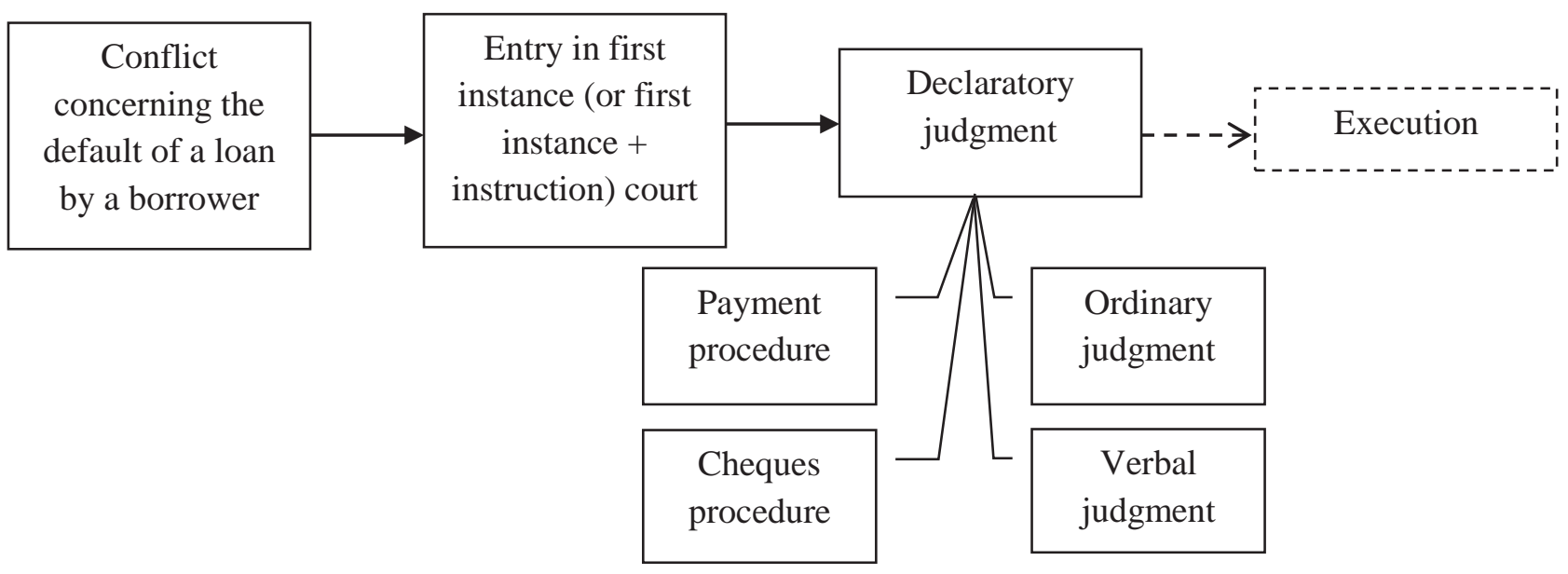

Source: Authors' own elaboration.

Using the court-level observations from the CGPJ database, and after aggregating the data at the regional level ${ }^{15}$, we have constructed an efficacy measure called the clearance rate both for the ordinary judgment (called declaratory in the rest of the paper to make the exposition simpler) and for the execution stage. $j$ stands for the province (there are 50 provinces) and $t$ for the year (2001-2012).

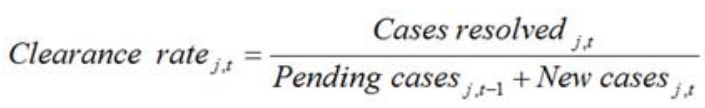

The clearance rate is defined as the ratio of resolved to total (new plus pending) cases. ${ }^{16} \mathrm{~A}$ high ratio means that a court is able to handle claims filed before it without generating substantial backlogs, i.e., the higher the rate, the higher the court's efficacy. Therefore, it is very similar to

\footnotetext{
14 The previous law dated from 1881. The new CPL is Law 1/2000 of Civil Procedure and entered into force on January $8^{\text {th }}, 2001$.

15 We have adequately merged data from the "first instance" courts and from the "first instance and instruction" courts at the local level taking into account their weight within the different provinces.

16 The information provided by the CGPJ database does not include the content of judgments, i.e., the \% of cases in which the judge decides in favour of the creditor or the debtor. This limits the possibilities to explore other issues such as potential judicial activism, which could also affect the availability of credit.
} 
the congestion rate used in previous literature [see Mora-Sanguinetti (2012) or Garcia-Posada and Mora-Sanguinetti (2014b)]. We have considered more appropriate to use the clearance rate in this paper because it has the advantage of having a quite symmetric distribution, unlike the congestion rate. ${ }^{17}$

The geographical variation in judicial efficacy is illustrated in Figure 2 and Figure 3, which show the average clearance rate of declaratory judgments and executions over the years of economic expansion (2001-2007) (map on the left) and recession (2008-2012) (map on the right) at the regional level. There was, on average, a difference of 0.29 percentage points between the most efficient (Álava) and the least efficient (Almeria) region throughout the period in the case of the declaratory judgment. The difference is also 0.29 percentage points in the case of executions, between Guipúzcoa (the most efficient on average) and Guadalajara (the least efficient). Figure 4 shows, for some regions, the variation through time of the clearance rate both for declarations and executions. ${ }^{18}$ The variability of clearance rates increased during the crisis.

Many factors may be behind the variations in the efficacy of justice, both across regions and over time, and may partially explain the differences observed, for example, between the north and the Mediterranean coast. The literature (Palumbo et al. 2013 and, very similarly, CEPEJ 2014) distinguishes between supply and demand factors that affect the efficacy of justice (which we measure here as the clearance rate). Supply factors are, amongst others, the budget of the judicial system and the allocation of human resources. Demand factors are, for instance, the size of the market for lawyers. Both sides (supply and demand) are affected by the design and quality of the procedural rules of the country.

On the supply side, the budget of the judicial system may differ across regions, as in Spain the administration of justice is transferred to the regional governments. A persistent fact is the greater efficacy of the courts of the Basque regions (Álava, Guipúzcoa and Vizcaya) compared to that of southern and eastern regions of Spain. Thus, this might have to do, among other factors, with the means available to the judicial system. Although it is not the aim of this article to explain what defines the performance of the judicial system, our models partially take into account these and other local factors. For example, in the absence of comprehensive information on the regions' budget for justice, our regressions include province fixed effects to control for cross-section heterogeneity in this dimension.

Regarding demand factors, it should be noted that among OECD member States, Spain is one of the countries with higher rates of litigation per capita (Palumbo et al. 2013). In addition, there are differences at the regional level in the number of lawyers per capita. Therefore, our estimates include a measure (lawyers per capita) following Carmignani and Giacomelli (2010) and Mora-Sanguinetti and Garoupa (2015). On the demand side, we should also note that the complexity of social and economic links is connected with the level of litigation. Both population density and immigration have had different profiles over time in different regions. The north is less populated than the south and, in addition, has received less immigration than

\footnotetext{
${ }^{17}$ Results using the congestion rate are available on demand. The literature also discusses other measures that we consider less comprehensive, such as the pending cases rate, the resolution rate or the pending- plus-new cases (PPNC) rate (see, among others, Mora-Sanguinetti, 2012). Furthermore, measuring the predictability or the accessibility of the system (Palumbo et al. 2013) are also methods of comparing judicial systems, but ultimately they depend on the duration of proceedings.

${ }^{18}$ Madrid is the capital of the country and the most populated region. Alicante is a coastal region, showing lower judicial efficacy. Navarra is a northern region, with high GDP per capita and high judicial efficacy.
} 
the south over the years of expansion. This factor will be taken into account in our analyses by including regions' population in our regression models.

In summary, several factors may partially explain the temporal and geographical differences in judicial performance (including the effect of the economic cycle, as it was mentioned in section 1). There are other factors, however, which have no geographical variation in Spain. For instance, the procedural rules (Civil Procedural Law) have no variation at the regional level.

Figure 2: Clearance rate of declaratory judgments: geographical variation.
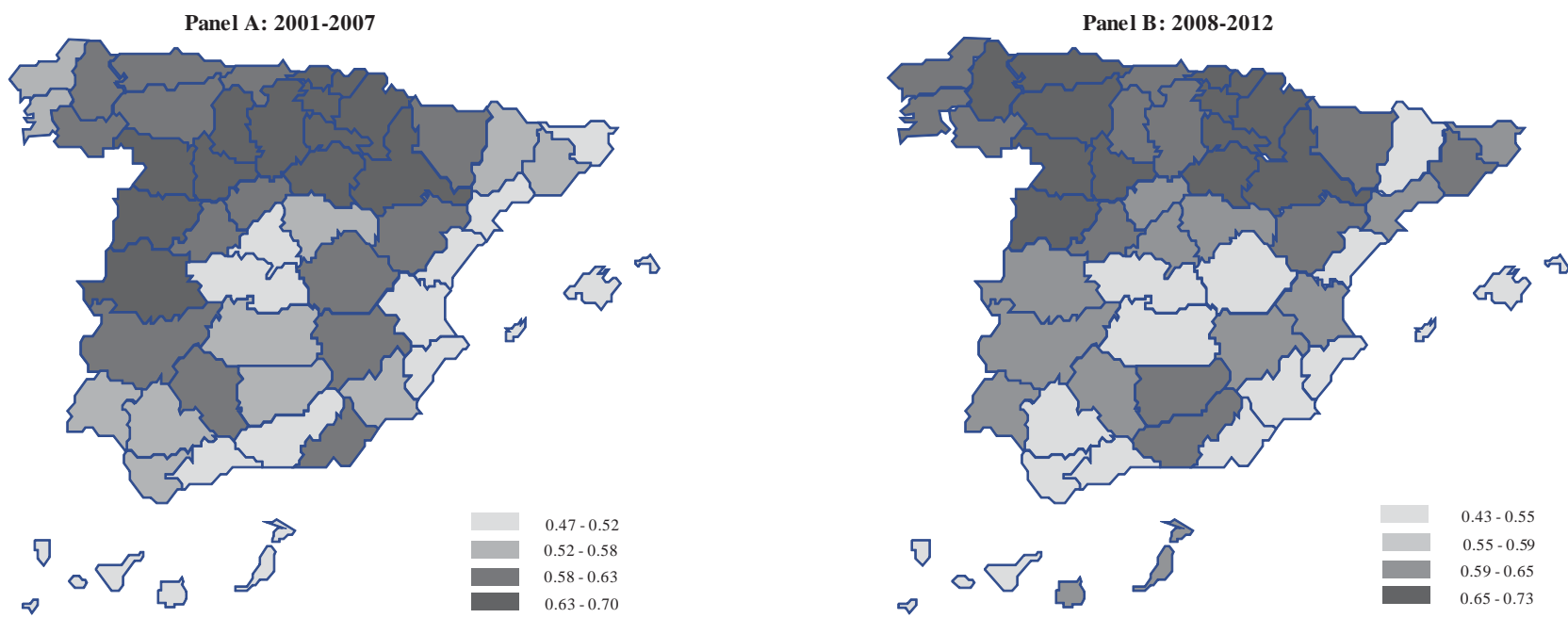

SOURCE: Self elaboration using CGPJ data.

Figure 3: Clearance rate of executions: geographical variation.
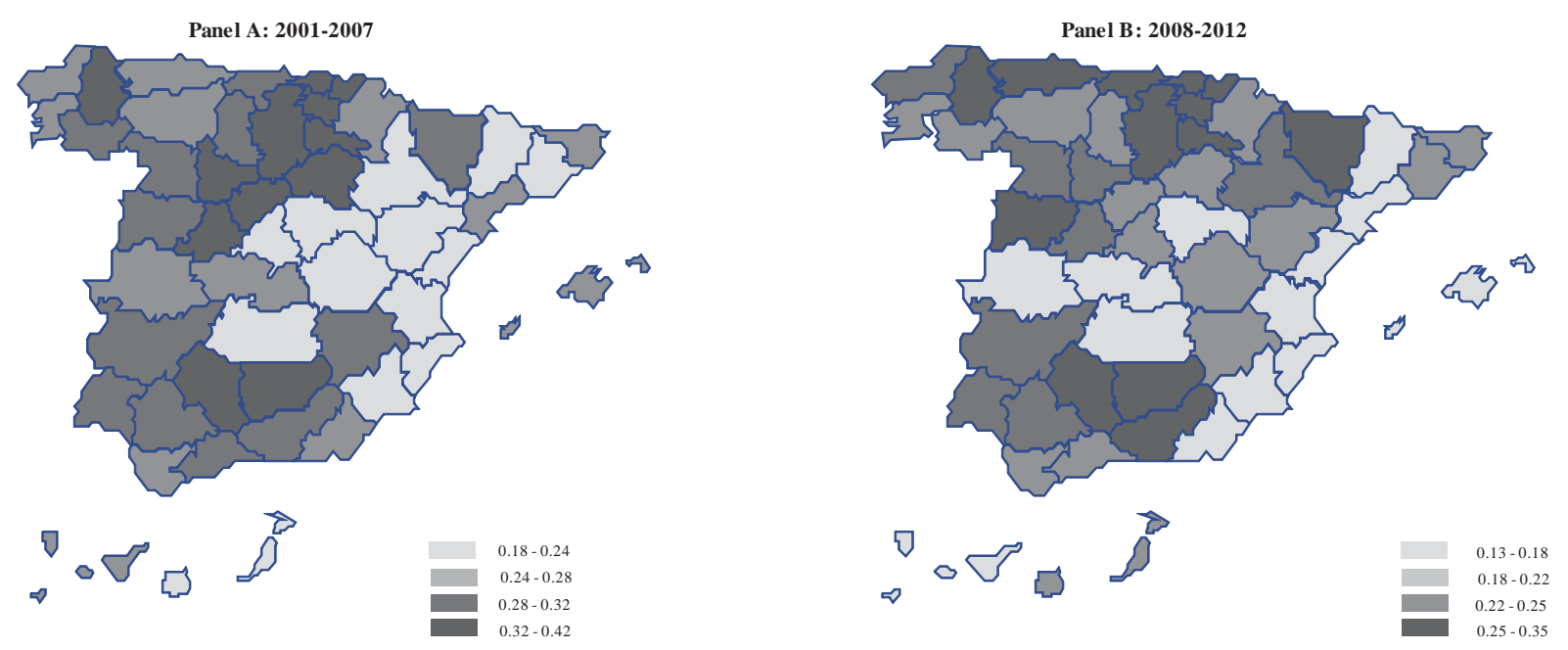

SOURCE: Self elaboration using CGPJ data. 
Figure 4: Clearance rate of declaratory judgments and executions

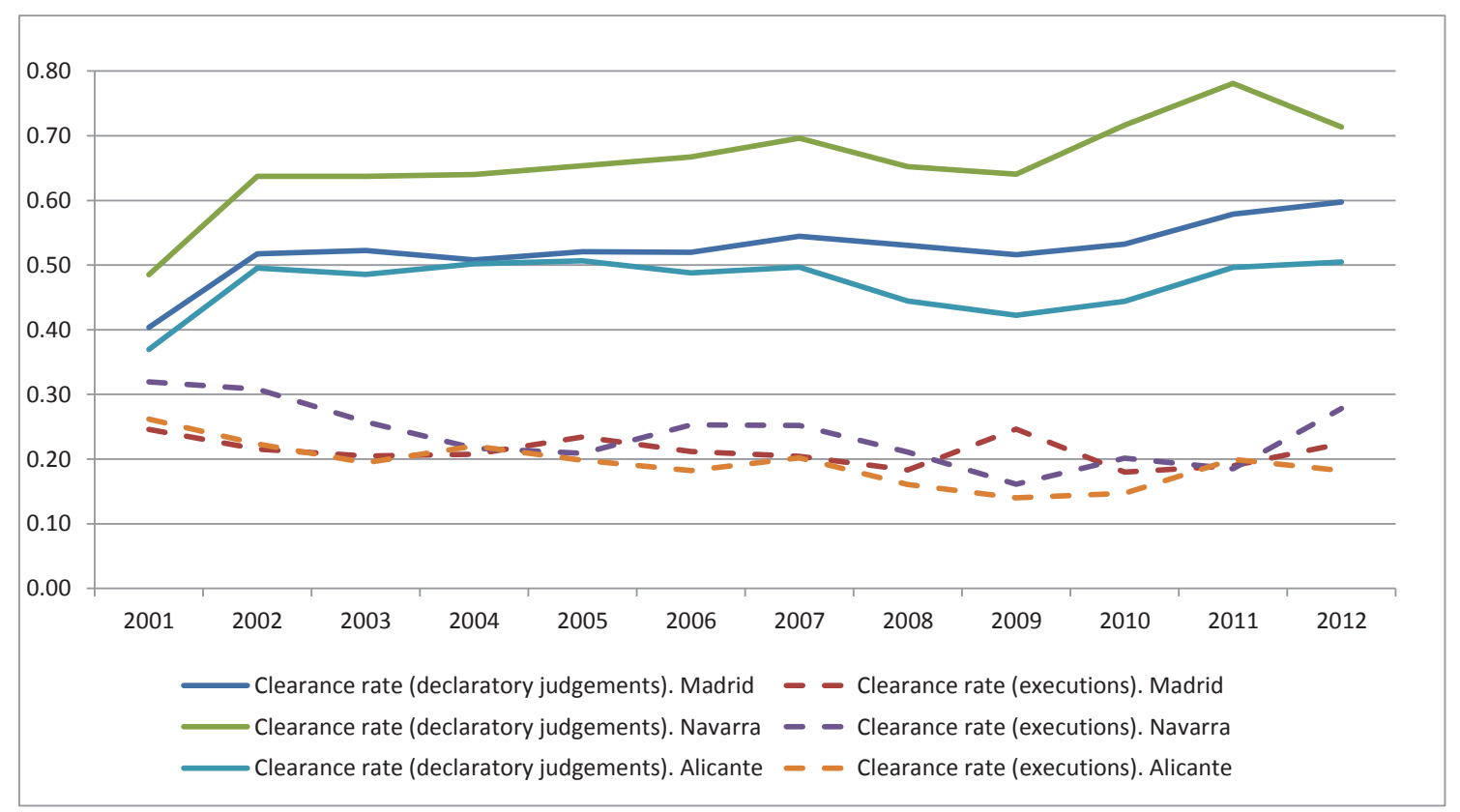

SOURCE: Self elaboration using CGPJ data.

\section{Measuring credit availability and related controls in the Spanish economy}

As already highlighted, credit availability seems to be a function of the efficacy of the legal system [Levine (1998), La Porta et al. (1997 and 1998), Desai et al. (2005), Ponticelli and Alencar (2016)]. To proxy credit availability, we use the ratio between the stock of credit granted by domestic and foreign financial institutions to Spanish firms and the regional GDP. This approach seems correct because banking credit to GDP ratio is a standard measure of financial development (Rajan and Zingales, 1995, Giacomelli and Menon, 2012), i.e., we expect higher ratios to be associated with less financial constraints. Credit data are obtained from the Banco de España's Credit Register (CIR), which contains information on all loans ${ }^{19}$ to nonfinancial Spanish companies ${ }^{20}$ granted ${ }^{21}$ by credit institutions operating in Spain ${ }^{22}$ over a reporting threshold of $6,000 €$. As loans to companies are normally much larger than the reporting threshold, we almost have the whole population of loans to those firms.

We also use the CIR to construct another key variable, the non-performing loans ratio (NPL ratio), which is the ratio between the stock of non-performing loans and the total amount of outstanding credit. We define as non-performing a loan that is in default or close to being in default. The regulation of the Banco de España establishes that a loan is non-performing if any

\footnotetext{
${ }^{19}$ We are including any instrument through which banks can provide credit to firms: financial loans, commercial loans, documentary credit, leasing, factoring, repos, securities lending and loans or credits transferred to a third party. ${ }^{20}$ Specifically, we include public limited companies, limited liability companies, unlimited liability companies and companies of a hybrid nature. We do not include sole proprietorships.

${ }^{21}$ Notice that we do not include undrawn credit facilities such as undrawn lines of credit.

22 All credit institutions that operate in Spain must report their credit exposures to the CIR. These comprise domestic credit institutions (commercial banks, savings banks, credit cooperatives and financial credit establishments) as well as foreign branches and subsidiaries of foreign banks.
} 
interest or principal payments are more than 90 days overdue (i.e., credit in arrears or delinquent credit) or there is any circumstance that makes the full repayment of the loan unlikely (for instance, doubtful credit because the debtor has filed for bankruptcy).

Figure 5 shows the time variation of our measures of credit. Most of the total credit as a percentage of the GDP is composed of performing loans. Therefore, the evolution of performing credit is very similar to the one of total credit, increasing during the expansion and contracting during the recession. Since the onset of the crisis the volume of non-performing loans rose significantly, increasing their weight in the total credit to non-financial corporations in the period 2008-2012.

Figure 5: Weight of performing and non-performing credit to non-financial corporations in Spain

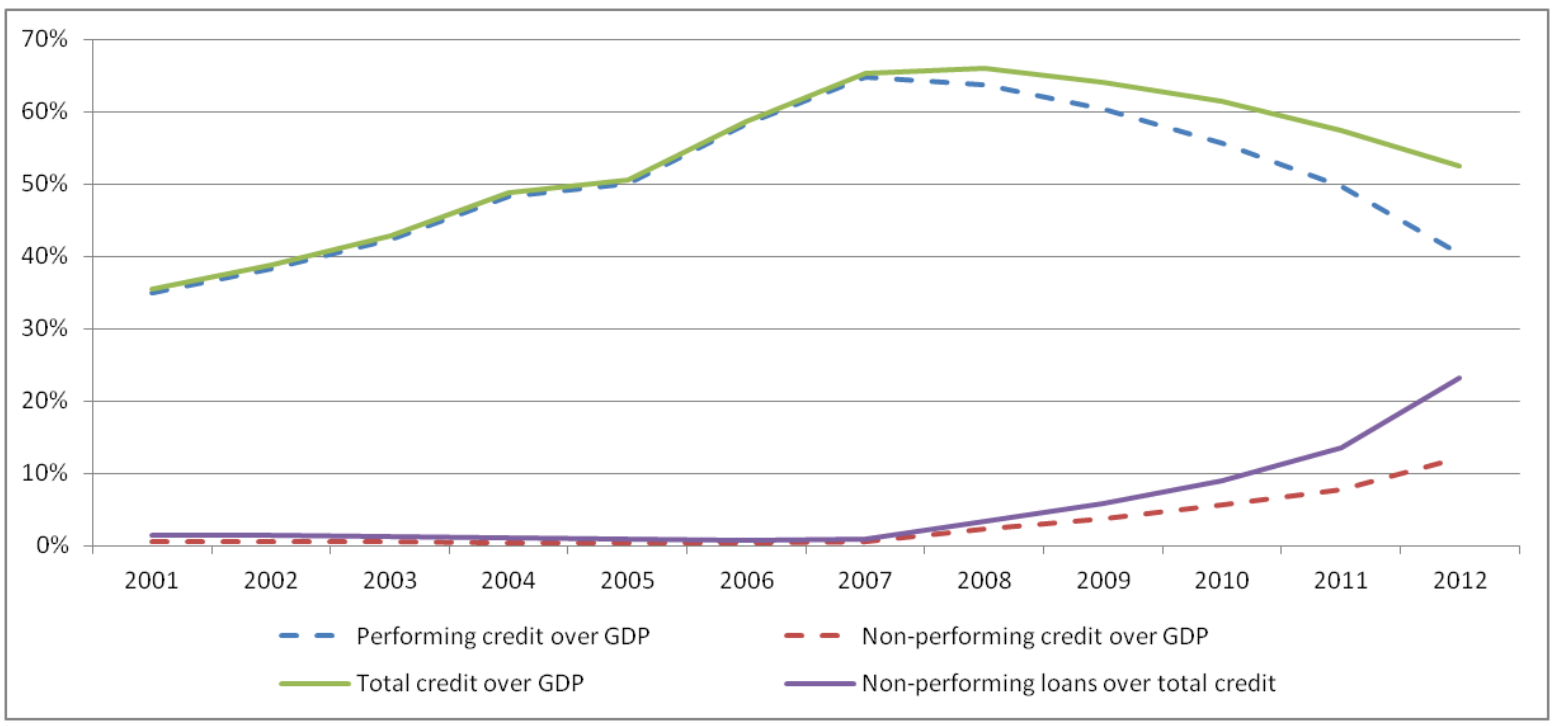

SOURCE: Self elaboration using CIR (Banco de España) data.

\subsection{Control variables}

As for the set of time-varying controls, we include the province Population (in logs) as a proxy of the potential market size, which is a determinant of the demand for credit. Following Carmignani and Giacomelli (2010) and Mora-Sanguinetti and Garoupa (2015), Lawyers per capita is also included as a proxy of the litigation intensity, as cheaper access to legal services may help firms grow but also congests the courts. We also include controls for the weight of different industries in the region, which could have deeply affected credit demand and supply. The exact definition of all variables, as well as all data sources, is provided in Table 1 . Table 2 displays the sample's descriptive statistics for the period 2001-2012. 
Table 1: Description of variables

\begin{tabular}{|c|c|c|c|}
\hline VARIABLE & DEFINITION & SCALE/UNIT & SOURCE \\
\hline $\begin{array}{l}\text { Non-performing loans/Total } \\
\text { credit }\end{array}$ & $\begin{array}{l}\text { Ratio between non-performing loans and total } \\
\text { performing and non-performing loans }\end{array}$ & $\%$ & $\begin{array}{l}\text { Banco de España and Spanish } \\
\text { National Statistics Institute (INE) }\end{array}$ \\
\hline Performing credit/GDP & Performing loans divided by GDP & $\%$ & Banco de España and INE \\
\hline Non-performing credit/GDP & Non-performing loans divided by GDP & $\%$ & Banco de España and INE \\
\hline Total credit/GDP & $\begin{array}{l}\text { Total performing and non-performing loans divided } \\
\text { by GDP }\end{array}$ & $\%$ & Banco de España and INE \\
\hline $\begin{array}{l}\text { Clearance rate (declaratory } \\
\text { judgments) }\end{array}$ & $\begin{array}{l}\text { Ratio between the cases resolved in a specific year } \\
\text { and the sum of pending cases (measured at the } \\
\text { beginning of the period) plus new cases in the same } \\
\text { year. The cases may be declaratory judgments or }\end{array}$ & Fraction & CGPJ \\
\hline Clearance rate (executions) & executions. & Fraction & CGPJ \\
\hline Lawyers per capita & $\begin{array}{l}\text { Number of lawyers inscribed in associations over } \\
\text { population }\end{array}$ & Fraction & Consejo General de la Abogacía \\
\hline Log(Population) & Number of people in logs & Logs & INE \\
\hline Weight of manufacturing & $\begin{array}{l}\text { Percentage of total workforce working on the } \\
\text { manufacturing sector }\end{array}$ & $\%$ & INE \\
\hline Weight of construction & $\begin{array}{l}\text { Percentage of total workforce working on the } \\
\text { construction sector }\end{array}$ & $\%$ & INE \\
\hline Weight of services & $\begin{array}{l}\text { Percentage of total workforce working on the } \\
\text { services sector }\end{array}$ & $\%$ & INE \\
\hline
\end{tabular}

Source: Authors' own elaboration.

Table 2: Descriptive statistics

\begin{tabular}{lccccc}
\hline Variable & Obs & Mean & Std. Dev. & Min & Max \\
\hline Non-performing loans/Total credit & 600 & 0.05 & 0.07 & 0.00 & 0.43 \\
Performing credit/GDP & 600 & 0.51 & 0.21 & 0.19 & 1.49 \\
Non-performing credit/GDP & 600 & 0.03 & 0.04 & 0.00 & 0.31 \\
Total credit/GDP & 600 & 0.53 & 0.21 & 0.19 & 1.52 \\
Clearance rate (declaratory judgment) & 600 & 0.58 & 0.08 & 0.34 & 0.78 \\
Clearance rate (executions) & 600 & 0.26 & 0.07 & 0.10 & 0.54 \\
Lawyers per capita & 600 & 1.98 & 0.91 & 0.40 & 16.73 \\
Log(Population) & 600 & 6.38 & 0.86 & 4.51 & 8.77 \\
Weight of manufacturing & 550 & 0.17 & 0.06 & 0.05 & 0.35 \\
Weight of construction & 550 & 0.12 & 0.03 & 0.05 & 0.23 \\
Weight of services & 550 & 0.64 & 0.08 & 0.44 & 0.87 \\
\hline
\end{tabular}

Source: Authors' own elaboration.

\subsection{Capturing the effect of the crisis}

As discussed in the introduction, the Spanish economy showed a negative quarterly GDP growth rate of $-1.4 \%$ in the fourth quarter of 2008 (quarterly growth rates were negative in all quarters of 2009). That was the beginning of a deep crisis in the Spanish economy that lasted until 2013, the so-called Great Recession.

Based on this information, we have constructed a dummy variable that captures the beginning of the crisis, so that we can distinguish two different periods in our sample: 2001-2007 and 20082012. We have then constructed the interaction between this dummy and our measures of 
judicial efficacy. This is the variable included in our regressions that we call Crisis interaction. ${ }^{23}$ The index $t$ refers to the year and $j$ to the province.

$$
\text { Crisis interaction }_{j t}=\left\{\begin{array}{c}
0 \text { if } t<2008 \\
1 * \text { Judicial Efficacy } \\
j \mathrm{jt}
\end{array} \text { if } t \geq 2008\right\}
$$

\section{$4 \quad$ Identification strategy}

We regress our proxies for credit availability on our measures of judicial efficacy, the interaction variable explained in the previous section, the group of relevant controls, regional fixed effects and time dummies (in order to capture the country-wide economic cycle).

Therefore, the estimates are obtained via the following specification:

$$
\text { Credit }_{j t}=\alpha_{j}+\beta \text { Judicial Efficacy }_{j t,}+\lambda \text { Crisis interaction }_{j t}+\sum_{k=1}^{K} \delta_{k} \text { Control }_{j t}^{k}+\sum_{t=1}^{T-1} \gamma_{t} d_{t}+\varepsilon_{j t}
$$

More specifically, "Credit" denotes one of our measures capturing the developments in the credit market (Total credit/GDP and the non-performing loans ratio). $\alpha_{j}$ are regional fixed effects, “Judicial Efficacy” measures efficacy of declaratory or execution judgments, "Control” is a set of $K$ control variables and $d_{t}$ are time dummies.

The above regressions are estimated via the within-group estimator with clustered standard errors robust to heteroskedasticity and serial correlation. The identification strategy relies on province fixed effects and time dummies to remove omitted-variable biases.

A potential source of concern in this analysis is reverse causality between judicial efficacy and credit availability. We could find a negative correlation between these two variables if there is more litigation in the provinces ${ }^{24}$ where more credit is available, which would lead to more backlogs in courts and, in turn, to lower judicial efficacy. For instance, more credit contracts may lead, ceteris paribus, to more defaults and other conflicts regarding those contracts. This would imply a downward bias in our estimates. In order to tackle this problem, in some specifications we include the variable Lawyers per capita as a proxy for the litigation intensity in a particular region. Nevertheless, in case some bias remained, our estimates would be the lower bound of the true causal impact. Another identification problem is the potential reverse causality between judicial efficacy and the NPL ratio. ${ }^{25}$ That is, provinces with low average

\footnotetext{
23 The effect of the crisis itself will be captured by time dummies in our regressions.

24 A parallel debate is whether we observe in the province " $j$ " the conflicts that actually took place in " $j$ " (or there may be some kind of "forum shopping"). The CPL (Articles 50 and 51) states that the competent court to resolve the conflict will be that of the domicile of the defendant, both in the case of natural and legal persons. Therefore, this limits the possible problem of "forum shopping" and makes the analysis at the province level in our experiment satisfactory. However, we must also note that the Law allows the parties to agree to choose another place to resolve the conflict (Article 55) and there is also a certain choice for the plaintiff while can also sue a businessman (defendant) in the place where he does business (in disputes arising from his business or professional activity). The latter should not be a big problem while interprovincial mobility in Spain is low (except in Madrid and Barcelona) but this rule may open the possibility of choosing the forum in some cases. Parallel to this, we cannot observe the cases where a creditor decided "not to sue" (in other words, we only observe the conflicts that actually take place).

25 We thank an anonymous referee for raising this point.
} 
NPL ratios may have less judicial backlogs and lower average court congestion, and in turn higher judicial efficacy. But this problem is ameliorated by the use of province fixed effects, as the fixed-effects estimator fits the relationship between judicial efficacy and the NPL ratio in deviations from the mean.

Another identification challenge comes from the fact that, during a deep recession, we may expect major policy changes that could affect both clearance rates and credit market outcomes such as credit availability and NPL ratios. Those policy changes would be confounding factors, implying that it may be difficult to disentangle their effect from that attributed to the Great Recession. To put it differently, our regression estimates would still be consistent, but our variable Crisis interaction would capture both the effect of the crisis itself and the policy responses to that crisis.

Indeed, there were key policy changes during our crisis period (2008-2012) that are expected to have a direct impact on the credit market. First, the current bankruptcy code (Ley Concursal), which was introduced in 2004, was reformed in 2009 and 2012 to cope with the rising number of corporate bankruptcies since 2008. For instance, formal workout negotiations on the brink of a bankruptcy filing were facilitated and the use of simplified, faster bankruptcy procedures for small firms was extended. ${ }^{26}$ Second, some major Spanish banking groups were required to increase their capital buffers after having been found to have capital shortfalls in the 2011 Capital Exercise of the European Banking Authority (EBA). Those banks could provide less credit to the private sector than their industry counterparts, as found by Méssonier and Monks (2015) for the euro area. Third, large capital shortfalls were identified by the "stress tests" conducted by independent consultants in the second half of 2012, following the Financial Assistance Programme for the Recapitalisation of Financial Institutions agreed by the Eurogroup in July 2012. ${ }^{27}$ Fourth, all Spanish banks were required by law to make large provisions to cover potential losses in their portfolios of loans and other assets related to the real estate sector in 2012. ${ }^{28}$ Therefore, the banks with a higher exposure to that sector faced more pressure on their capital buffers and had less money available for lending to firms and households. Fifth, in December 2012 there was a transfer of assets -mainly loans to construction and real estate companies- from the four nationalised ${ }^{29}$ Spanish financial institutions to the so-called "bad bank", SAREB (Company for the Management of Assets proceeding from Restructuring of the Banking System). By allowing nationalized banks to sell (at a high discount) their non-performing loans and other problematic assets to SAREB, Spanish authorities expected to provide those banks with more liquidity that could be turned into credit to the real economy. Finally, one may think that the ECB's Outright Monetary Transactions (OMT) program, announced on 2 August 2012,by dramatically reducing sovereign spreads, also eased banks' funding conditions, which could have a positive influence on credit supply.

\footnotetext{
${ }^{26}$ For a discussion of the Spanish bankruptcy code and its two first reforms see Celentani et al. (2012).

27 The European Stability Mechanism disbursed a total of $€ 41.3$ billion to the Spanish government for the recapitalisation of the country's banking sector.

${ }^{28}$ Following the Royal Decree Law 2/2012 of February 3 and the Royal Decree Law 18/2012 of May 11, all banks had to make higher provisions on non-performing loans to real estate companies as well as provisions on performing loans to these companies and on land and buildings owned by the banks as a consequence of collateral repossession and dation in payment.

29 BFA-Bankia, Catalunya Banc, NCG Banco-Banco Gallego and Banco de Valencia.
} 


\section{$5 \quad$ Results}

Table 3 shows pairwise correlations among all variables. There is a sizeable negative correlation between the total credit to GDP ratio and the clearance rate of executions. In other words, there is a negative correlation between judicial efficacy and credit availability at the execution stage. This may be due to reverse causality between credit availability and judicial efficacy, as previously discussed. However, when we move to our panel regressions, we can introduce a wide set of controls for time-varying and time-invariant regional heterogeneity and for the evolution of the business cycle. Thus, the effect of judicial efficacy on credit availability requires a detailed analysis.

Tables 4 and 5 present the impact of the clearance rate on credit availability at the declaratory stage and at the execution stage, respectively. Tables 6 and 7 present the impact of the clearance rate on the non-performing loan ratio at those stages. Tables are structured as follows: column (1) shows the coefficient of the main regressor when no controls are included; column (2) includes province fixed effects; column (3) includes the interaction of the clearance rate with the crisis dummy, time-varying and province fixed effects; column (4) adds to (3) a set of industrial composition controls; column (5) includes a proxy for market size of the province ("population", in logs) and a proxy for litigation intensity through the variable "lawyers per capita".

The positive and statistically significant coefficient on the clearance rate throughout columns (3)-(5) in Table 5 suggests that greater efficacy of courts in execution judgments promotes credit availability in a region. This effect seems to be stable over the business cycle, as the coefficient on "Crisis interaction" is not statistically different from zero. By contrast, the clearance rate has no significant impact on credit availability in the case of declaratory judgments (Table 4) ${ }^{30}$.

The economic crisis has changed the relation between court enforcement and the default rate, as proxied by the non-performing loan ratio (see Table 6 and Table 7). During the economic expansion (2001-2007), judicial efficacy, whether at the execution or at the declaratory stage, did not have a significant impact on the default rate. This may be explained by the fact that fast economic growth and rising collateral values related with the housing boom kept nonperforming loan (NPL) ratios at historically low levels with little variation over time. ${ }^{31}$ However, during the "Great Recession", that process was reversed and NPL ratios soared as many firms experienced financial difficulties. Consequently, we find that judicial efficacy at the declaration stage significantly reduced default rates during the crisis, while court enforcement at the executive stage had no significant effect.

As it was discussed in section 1, these findings may have to do with the proportions of strategic and non-strategic defaults.

\footnotetext{
${ }^{30}$ As already noted, this analysis is performed for the ordinary procedures, which are the most consistent procedures with the type of loans for which we have information (those with an amount higher than 6,000 euros). If we perform the analysis for verbal judgments, we find that a higher judicial efficacy in resolving this type of cases also contributes to reducing the default rate, especially during the crisis. However, no significant impact is found when estimating its effect on credit availability.

${ }^{31}$ Note that we estimate a fixed effects model with the within-group estimator, which exploits variation over time within each region.
} 
Finally, the control variables have the expected impact when their coefficients are significant. The coefficient on "population" is positive, suggesting that a larger market leads to more credit availability. "Lawyers per capita" is also positively correlated with total credit availability, suggesting that a greater access to judicial services eases credit constraints. Neither variable has a significant impact on the non-performing loans ratio.

Table 3: Regressors' correlation matrix (pairwise correlations).

\begin{tabular}{|c|c|c|c|c|c|c|c|c|c|c|c|}
\hline & $\begin{array}{c}\text { Non- } \\
\text { performing } \\
\text { loans/Total } \\
\text { credit }\end{array}$ & $\begin{array}{c}\text { Total } \\
\text { credit/GDP }\end{array}$ & $\begin{array}{l}\text { Performing } \\
\text { credit/GDP }\end{array}$ & $\begin{array}{c}\text { Non- } \\
\text { performing } \\
\text { credit/GDP }\end{array}$ & $\begin{array}{c}\text { Clearance rate } \\
\text { (declaratory } \\
\text { judgment) }\end{array}$ & $\begin{array}{c}\text { Clearance } \\
\text { rate } \\
\text { (executions) }\end{array}$ & $\begin{array}{c}\begin{array}{c}\text { Weight of } \\
\text { manufacturing }\end{array}\end{array}$ & $\begin{array}{c}\text { Weight of } \\
\text { construction }\end{array}$ & $\begin{array}{l}\text { Weight of } \\
\text { services }\end{array}$ & $\begin{array}{l}\text { Lawyers } \\
\text { per capita }\end{array}$ & $\begin{array}{c}\text { Log } \\
\text { (Population) }\end{array}$ \\
\hline Non-performing loans/Total credit & 1 & & & & & & & & & & \\
\hline Total credit/GDP & -0.0847 & 1 & & & & & & & & & \\
\hline Performing credit/GDP & -0.3098 & 0.9708 & 1 & & & & & & & & \\
\hline Non-performing credit/GDP & 0.9136 & 0.1949 & -0.0463 & 1 & & & & & & & \\
\hline Clearance rate (declaratory judgment) & 0.0515 & -0.0502 & -0.2453 & -0.0943 & 1 & & & & & & \\
\hline Clearance rate (executions) & -0.2838 & -0.2553 & -0.0775 & -0.2347 & 0.595 & 1 & & & & & \\
\hline Weight of manufacturing & -0.2256 & 0.065 & 0.1133 & -0.1925 & 0.3892 & 0.2092 & 1 & & & & \\
\hline Weight of construction & -0.5592 & -0.1381 & -0.0015 & -0.5683 & -0.2784 & -0.0271 & -0.1007 & 1 & & & \\
\hline Weight of services & 0.4234 & 0.276 & 0.1673 & 0.4652 & -0.1982 & -0.1852 & -0.5677 & -0.4979 & 1 & & \\
\hline Lawyers per capita & 0.046 & 0.3883 & 0.3597 & 0.1463 & -0.05 & -0.0016 & -0.1201 & -0.25 & 0.4209 & 1 & \\
\hline Log(Population) & 0.0506 & 0.5389 & 0.5013 & 0.1943 & -0.3617 & -0.1379 & -0.2238 & -0.1837 & 0.5892 & 0.4717 & 1 \\
\hline
\end{tabular}

SOURCE: Authors' own elaboration.

Table 4: Impact of judicial efficacy on credit availability. Declaratory judgments.

\begin{tabular}{|c|c|c|c|c|c|}
\hline MODEL & 1 & 2 & 3 & 4 & 5 \\
\hline DEPENDENT VARIABLE & \multicolumn{5}{|c|}{ Total cre dit/GDP } \\
\hline Clearance rate (declaratory judgements) & $\begin{array}{c}0.439 * * * \\
(0.101)\end{array}$ & $\begin{array}{c}0.520^{* * *} \\
(0.122)\end{array}$ & $\begin{array}{c}0.319 \\
(0.217)\end{array}$ & $\begin{array}{c}0.358 \\
(0.235)\end{array}$ & $\begin{array}{c}0.131 \\
(0.284)\end{array}$ \\
\hline Crisis interaction & & & $\begin{array}{c}-0.450^{* *} \\
(0.195)\end{array}$ & $\begin{array}{c}-0.485^{* *} \\
(0.206)\end{array}$ & $\begin{array}{l}-0.114 \\
(0.215)\end{array}$ \\
\hline Weight of manufacturing & & & & $\begin{array}{c}-1.498^{* *} \\
(0.673)\end{array}$ & $\begin{array}{l}-1.125^{*} \\
(0.597)\end{array}$ \\
\hline Weight of construction & & & & $\begin{array}{l}-0.497 \\
(0.511)\end{array}$ & $\begin{array}{l}-0.257 \\
(0.528)\end{array}$ \\
\hline Weight of services & & & & $\begin{array}{c}-1.239 * * \\
(0.487)\end{array}$ & $\begin{array}{c}-0.902 * * \\
(0.435)\end{array}$ \\
\hline Lawyers per capita & & & & & $\begin{array}{c}0.0053 * * \\
(0.0021)\end{array}$ \\
\hline Log (population) & & & & & $\begin{array}{l}0.817^{*} \\
(0.411)\end{array}$ \\
\hline Constant & $\begin{array}{c}0.279 * * * \\
(0.0636)\end{array}$ & $\begin{array}{c}0.232 * * * \\
(0.0713)\end{array}$ & $\begin{array}{l}0.211^{* *} \\
(0.105)\end{array}$ & $\begin{array}{l}1.248^{* *} \\
(0.466)\end{array}$ & $\begin{array}{l}-4.086 \\
(2.469)\end{array}$ \\
\hline Province fixed effects & NO & YES & YES & YES & YES \\
\hline Time dummies & NO & NO & YES & YES & YES \\
\hline Observations & 600 & 600 & 600 & 550 & 550 \\
\hline R-squared & & 0.043 & 0.551 & 0.517 & 0.542 \\
\hline Clustered provinces & 50 & 50 & 50 & 50 & 50 \\
\hline
\end{tabular}

SOURCE: Authors' own elaboration. 
Table 5: Impact of judicial efficacy on credit availability. Executions.

\begin{tabular}{|c|c|c|c|c|c|}
\hline MODEL & 1 & 2 & 3 & 4 & 5 \\
\hline DEPENDENT VARIABLE & \multicolumn{5}{|c|}{ Total credit/GDP } \\
\hline Clearance rate (executions) & $\begin{array}{c}-0.864^{* * *} \\
(0.0911)\end{array}$ & $\begin{array}{c}-0.884^{* * *} \\
(0.187)\end{array}$ & $\begin{array}{c}0.380^{* *} \\
(0.155)\end{array}$ & $\begin{array}{c}0.433^{* *} \\
(0.176)\end{array}$ & $\begin{array}{c}0.316^{* *} \\
(0.154)\end{array}$ \\
\hline Crisis interaction & & & $\begin{array}{l}-0.109 \\
(0.190)\end{array}$ & $\begin{array}{l}-0.156 \\
(0.168)\end{array}$ & $\begin{array}{c}0.171 \\
(0.222)\end{array}$ \\
\hline Weight of manufacturing & & & & $\begin{array}{c}-1.513^{* *} \\
(0.664)\end{array}$ & $\begin{array}{l}-1.019 * \\
(0.577)\end{array}$ \\
\hline Weight of construction & & & & $\begin{array}{l}-0.830 \\
(0.566)\end{array}$ & $\begin{array}{l}-0.391 \\
(0.528)\end{array}$ \\
\hline Weight of services & & & & $\begin{array}{c}-1.188^{* *} \\
(0.507)\end{array}$ & $\begin{array}{l}-0.860 * \\
(0.448)\end{array}$ \\
\hline Lawyers per capita & & & & & $\begin{array}{c}0.0061^{* * *} \\
(0.0022)\end{array}$ \\
\hline Log (population) & & & & & $\begin{array}{c}0.900 * * \\
(0.407)\end{array}$ \\
\hline Constant & $\begin{array}{c}0.759 * * * \\
(0.0334)\end{array}$ & $\begin{array}{c}0.764^{* * *} \\
(0.0484)\end{array}$ & $\begin{array}{c}0.229 * * * \\
(0.0567)\end{array}$ & $\begin{array}{c}1.341^{* * *} \\
(0.442)\end{array}$ & $\begin{array}{l}-4.663^{*} \\
(2.531)\end{array}$ \\
\hline Province fixed effects & NO & YES & YES & YES & YES \\
\hline Time dummies & NO & NO & YES & YES & YES \\
\hline Observations & 600 & 600 & 600 & 550 & 550 \\
\hline R-squared & & 0.140 & 0.552 & 0.522 & 0.555 \\
\hline Clustered provinces & 50 & 50 & 50 & 50 & 50 \\
\hline
\end{tabular}

SOURCE: Authors' own elaboration. 
Table 6: Impact of judicial efficacy on non-performing loans (NPL) ratio. Declaratory judgments.

\begin{tabular}{|c|c|c|c|c|c|}
\hline MODEL & 1 & 2 & 3 & 4 & 5 \\
\hline DEPENDENT VARIABLE & \multicolumn{5}{|c|}{ Non-performing loans/Total cre dit } \\
\hline Clearance rate (declaratory judgements) & $\begin{array}{c}0.0476 \\
(0.0378)\end{array}$ & $\begin{array}{c}0.265 * * * \\
(0.0553)\end{array}$ & $\begin{array}{l}-0.0380 \\
(0.0593)\end{array}$ & $\begin{array}{l}-0.0833 \\
(0.0689)\end{array}$ & $\begin{array}{l}-0.0810 \\
(0.0618)\end{array}$ \\
\hline Crisis interaction & & & $\begin{array}{c}-0.269 * * * \\
(0.0611)\end{array}$ & $\begin{array}{c}-0.168^{* * *} \\
(0.0585)\end{array}$ & $\begin{array}{c}-0.172 * * * \\
(0.0590)\end{array}$ \\
\hline Weight of manufacturing & & & & $\begin{array}{c}-0.254^{* *} \\
(0.108)\end{array}$ & $\begin{array}{c}-0.258^{* *} \\
(0.119)\end{array}$ \\
\hline Weight of construction & & & & $\begin{array}{c}-0.547^{* * *} \\
(0.148)\end{array}$ & $\begin{array}{c}-0.549 * * * \\
(0.152)\end{array}$ \\
\hline Weight of services & & & & $\begin{array}{l}-0.0415 \\
(0.105)\end{array}$ & $\begin{array}{l}-0.0452 \\
(0.112)\end{array}$ \\
\hline Lawyers per capita & & & & & $\begin{array}{c}-0.00025 \\
(0.0005)\end{array}$ \\
\hline Log (population) & & & & & $\begin{array}{c}-0.00878 \\
(0.0701)\end{array}$ \\
\hline Constant & $\begin{array}{c}0.0248 \\
(0.0222)\end{array}$ & $\begin{array}{c}-0.102^{* * *} \\
(0.0323)\end{array}$ & $\begin{array}{c}0.0323 \\
(0.0262)\end{array}$ & $\begin{array}{l}0.205^{* *} \\
(0.100)\end{array}$ & $\begin{array}{c}0.263 \\
(0.498)\end{array}$ \\
\hline Province fixed effects & NO & YES & YES & YES & YES \\
\hline Time dummies & NO & NO & YES & YES & YES \\
\hline Observations & 600 & 600 & 600 & 550 & 550 \\
\hline R-squared & & 0.039 & 0.854 & 0.861 & 0.861 \\
\hline Clustered provinces & 50 & 50 & 50 & 50 & 50 \\
\hline
\end{tabular}

SOURCE: Authors' own elaboration. 
Table 7: Impact of judicial efficacy on non-performing loans (NPL) ratio. Executions.

\begin{tabular}{|c|c|c|c|c|c|}
\hline MODEL & 1 & 2 & 3 & 4 & 5 \\
\hline DEPENDENT VARIABLE & \multicolumn{5}{|c|}{ Non-performing loans/Total credit } \\
\hline Clearance rate (executions) & $\begin{array}{c}-0.264^{* * *} \\
(0.0365)\end{array}$ & $\begin{array}{c}-0.443^{* * *} \\
(0.0704)\end{array}$ & $\begin{array}{c}0.0142 \\
(0.0402)\end{array}$ & $\begin{array}{l}-0.0109 \\
(0.0459)\end{array}$ & $\begin{array}{l}-0.0162 \\
(0.0436)\end{array}$ \\
\hline Crisis interaction & & & $\begin{array}{c}-0.214^{* * *} \\
(0.0681)\end{array}$ & $\begin{array}{l}-0.125^{*} \\
(0.0734)\end{array}$ & $\begin{array}{c}-0.110 \\
(0.0791)\end{array}$ \\
\hline Weight of manufacturing & & & & $\begin{array}{c}-0.304^{* * *} \\
(0.109)\end{array}$ & $\begin{array}{c}-0.281^{* *} \\
(0.113)\end{array}$ \\
\hline Weight of construction & & & & $\begin{array}{c}-0.699 * * * \\
(0.169)\end{array}$ & $\begin{array}{c}-0.679 * * * \\
(0.166)\end{array}$ \\
\hline Weight of services & & & & $\begin{array}{l}-0.0473 \\
(0.109)\end{array}$ & $\begin{array}{l}-0.0325 \\
(0.114)\end{array}$ \\
\hline Lawyers per capita & & & & & $\begin{array}{r}6.39 e-05 \\
(0.00077)\end{array}$ \\
\hline Log (population) & & & & & $\begin{array}{c}0.0408 \\
(0.0735)\end{array}$ \\
\hline Constant & $\begin{array}{c}0.121^{* * *} \\
(0.0099)\end{array}$ & $\begin{array}{c}0.168 * * * \\
(0.0183)\end{array}$ & $\begin{array}{c}0.0104 \\
(0.0126)\end{array}$ & $\begin{array}{l}0.191^{* *} \\
(0.0844)\end{array}$ & $\begin{array}{l}-0.0805 \\
(0.497)\end{array}$ \\
\hline Province fixed effects & NO & YES & YES & YES & YES \\
\hline Time dummies & NO & NO & YES & YES & YES \\
\hline Observations & 600 & 600 & 600 & 550 & 550 \\
\hline R-squared & & 0.123 & 0.839 & 0.854 & 0.854 \\
\hline Clustered provinces & 50 & 50 & 50 & 50 & 50 \\
\hline
\end{tabular}

SOURCE: Authors' own elaboration. 


\section{Conclusions}

A number of theoretical and empirical studies have found that the efficacy with which agents can enforce their contracts in an economy and, in this regard, the performance of the judicial system, is a crucial determinant for the development of the credit market and partially explains the restrictions experienced by some economic actors when accessing credit. This literature has not studied, however, which is the differential impact of distinct legal procedures in a particular country and how these procedures interact with the business cycle.

This study analyzes how the quality of enforcement institutions explains differences in the availability of credit in the Spanish economy at the local level. Recent judicial data are exploited, covering the years since the introduction of the new Civil Procedure Law of 2000 and the effects of both the "declaratory" stage of the procedure and its "execution" throughout the period of expansion of the Spanish economy (2001- 2007) and during the period of the "Great Recession" (2008-2012) are explored.

It is found that higher judicial inefficacy reduces the availability of credit with respect to regional GDP (credit/GDP) throughout the business cycle. Crucially, the significance of the impact depends on the type of the procedure: only the quality of the "execution" stage of the procedure (i.e., when the judge enforces the repayment of a debt), and not the "declaratory" stage (i.e., when a debt is verified by a judge) is relevant in quantitative terms. Specifically, a rise in the clearance rate of executions is associated with an increase in the ratio of total credit to GDP. A possible explanation to this finding is that, throughout the economic cycle, a relevant proportion of the defaults that take place are strategic (i.e., defaults by a solvent debtor). In such a situation, lenders rely on the efficacy of execution procedures (for instance, seizure of loan collateral by a court) to recover loans, and they are only willing to provide credit ex-ante if those procedures deter moral hazard and strategic defaults.

When analyzing the determinants of the non-performing loans ratios it is found that during the economic expansion (2001-2007), judicial efficacy did not have a significant impact, neither at the execution nor at the declaratory stage. However, during the "Great Recession" (2008-2012) judicial efficacy at the declaratory stage had a significant impact on NPL ratios, while court enforcement at the execution stage had no effect. A plausible explanation to this finding is that non-strategic defaults (i.e., defaults caused by the debtor's inability to honor his debts) are much more frequent during recessions than strategic defaults, because borrowers' cash flows and collateral values are very low. In that case, what matters is the judicial efficacy at the declaration stage (i.e., when the existence of a debt is declared and acknowledged by a judge), as debtors do not voluntarily default on their obligations, implying that they do not need to be forced to repay their debts.

While the Spanish judicial system seems to suffer from higher general inefficacy than that of neighboring countries (Palumbo et al. 2013), this paper proposed a guide on where to concentrate efforts to optimize the resources invested in the Spanish judicial system. As a more general conclusion, these findings warn that the use of "aggregate" measures of civil efficacy, as done in the previous literature, may provide an incomplete view of the problem. 
1. Aghion, P., Fally, T. and S. Scarpetta (2007). Credit constraints as a barrier to the entry and post-entry growth of firms. Economic Policy, 22: 731-779.

2. Bae, K. H. and V. K. Goyal (2009). Creditor Rights, Enforcement, and Bank Loans. Journal of Finance, 64(2): 823-860.

3. Berger, A. N. and J. F. Udell (2003). The institutional memory hypothesis and the procyclicality of bank lending behaviour. BIS Working Papers No 125.

4. Beck, T., Demirguc-Kunt, A., Laeven, L., and R. Levine (2008). Finance, firm size, and growth. Journal of Money, Credit and Banking, 40(7): 1379-1405.

5. Bentolila, S., M. Jansen, G. Jiménez and S. Ruano (2015). "When Credit Dries Up: Job Losses in the Great Recession," CEMFI Working Paper No. 1310.

6. Carmignani, A. and S. Giacomelli (2010). Too many lawyers? Litigation in Italian civil courts. Temi di discussion (working papers), 745, Banca d'Italia.

7. Celentani, M., García-Posada, M and F. Gómez, (2012). The Spanish Business Bankruptcy Puzzle, mimeo.

8. CEPEJ - European Commission for the Efficiency of Justice (2014). Report on "European judicial systems - Edition 2014 (2012 data): efficiency and quality of justice".

9. Chemin, M. (2009). The impact of the judiciary on entrepreneurship: Evaluation of Pakistan's Access to Justice Programme. Journal of Public Economics 93(1-2): 114-125.

10. Chemin, M. (2012). Does court speed shape economic activity? Evidence from a court reform in India. Journal of Law Economics and Organization, 28(3): 460-485.

11. Desai, M., P. Gompers and J. Lerner (2005). Institutions, capital constraints and entrepreneurial firm dynamics: evidence from Europe, Harvard NOM Working Paper No. 03-59.

12. Djankov, S., R. La Porta, F. López de Silanes and A. Shleifer (2003). Courts. The Quarterly Journal of Economics, 118: 453-517.

13. Djankov, S., O. Hart, C. McLiesh and A. Shleifer (2008), "Debt Enforcement Around the World", Journal of Political Economy, 116(6): 1105-49.

14. Evans, D. S. and B. Jovanovic (1989). An Estimated Model of Entrepreneurial Choice under Liquidity Constraints. Journal of Political Economy 97(4): 808-827.

15. Fabbri, D. (2010), Law Enforcement and Firm Financing: Theory and Evidence. Journal of the European Economic Association, 8(4): 776-816.

16. Fabbri, D. and M. Padula (2004). Does poor legal enforcement make households creditconstrained? Journal of Banking \& Finance 28(10): 2369-2397.

17. Gan, J. (2007). The real effects of asset market bubbles: loan- and firm-level evidence of a lending channel. Review of Financial Studies, No. 20, 1941-1973.

18. García-Posada, M. and J. S. Mora-Sanguinetti (2015a). Does (average) size matter? Court enforcement, business demography and firm growth. Small Business Economics Journal, 44 (3), 639-669.

19. García-Posada, M. and J. S. Mora-Sanguinetti (2015b) "Entrepreneurship and Enforcement Institutions: Disaggregated Evidence for Spain" European Journal of Law and Economics, 40 (1), 49-74. 
20. García-Posada, M. and M. A. Marchetti (2015). "The bank lending channel of unconventional monetary policy: the impact of the VLTROs on credit supply in Spain". Banco de España Working Paper 1512.

21. Giacomelli, S. and C. Menon (2012). Firm Size and Judicial Efficiency in Italy: Evidence from the Neighbour's Tribunal. SERC Discussion Papers 0108, Spatial Economics Research Centre, LSE.

22. Ginsburg and Hoetker (2006). The Unreluctant Litigant? An Empirical Analysis of Japan's Turn to Litigation. Journal of Legal Studies, 35: 31-59

23. Global Entrepreneurship Monitor (2011). Informe GEM España 2011. Global Entrepreneurship Research Association.

24. Jappelli, T., M. Pagano and M. Bianco (2005). Courts and banks: effects of judicial enforcement on credit markets, Journal of Money Credit and Banking, 37: 224-244.

25. Jimenez, G., S. Ongena, J. Peydro-Alcalde and J. Saurina (2012): "Credit Supply and Monetary Policy: Identifying the Bank Balance-Sheet Channel with Loan Applications, The American Economic Review, Vol. 102 No.5, pp. 2301-2326.

26. Jimeno, J. F., and T. Santos (2014). The crisis of the Spanish economy. SERIEs, Journal of the Spanish Economic Association, 5 (2-3), pp. 125-141.

27. Khwaja, A. A. Mian (2008). Tracing the Impact of Bank Liquidity Shocks: Evidence from an Emerging Market. American Economic Review, 98(4), 1413-42.

28. Laeven, L., and Majnoni, G. (2005). Does judicial efficiency lower the cost of credit? Journal of Banking and Finance, 29(7), 1791-1812.

29. La Porta, R., F. López de Silanes, A. Schleifer and R. W. Vishny (1997). Legal determinants of external finance. Journal of Finance, 52: 1131-1150.

30. La Porta, R., F. López De Silanes, A. Schleifer and R. W. Vishny (1998). Law and finance. Journal of Political Economy, 106: 1113-1155.

31. Levine, R. (1998). The Legal Environment, Banks, and Long-Run Economic Growth. Journal of Money, Credit and Banking 30(3): 596-613.

32. Lown, C. and D. P Morgan (2006). The Credit Cycle and the Business Cycle: New Findings Using the Loan Officer Opinion Survey. Journal of Money, Credit, and Banking, Vol. 38, No. 6.

33. Méssonier, J. and A. Monks (2015): "Did the EBA Capital Exercise Cause a Credit Crunch in the Euro Area?," International Journal of Central Banking, June.

34. Mora-Sanguinetti, J. S. (2010). "A Characterization of the Judicial System in Spain: Analysis with Formalism Indices”. Economic Analysis of Law Review 1 (2). 210-240.

35. Mora-Sanguinetti, J. S. (2012). Is judicial inefficacy increasing the weight of the house property market in Spain? Evidence at the local level. SERIEs, Journal of the Spanish Economic Association 3 (3): 339-365.

36. Mora-Sanguinetti, J. S. and N. Garoupa (2015) "Do lawyers induce litigation? Evidence from Spain, 2001-2010". International Review of Law and Economics 44. 29-41.

37. OECD (2013). What makes civil justice effective? OECD Economics Department Policy Notes 18 June 2013. 
38. Palumbo, G., Giupponi, G., Nunziata, L. and J. S. Mora-Sanguinetti (2013). "The Economics of Civil Justice: New Cross-Country Data and Empirics". OECD Economics Department Working Papers No. 1060.

39. Pinneiro, A. C., and C. Cabral (1999). Credit markets in Brazil: the role of judicial enforcement and other institutions. BIS Working Paper No. 368.

40. Ponticelli, J. and L. Alencar (2016). Court Enforcement, Bank Loans and Firm Investment: Evidence from a Bankruptcy Reform in Brazil. Banco Central do Brasil Working Paper 425.

41. Qian, J. and P. Strahan (2007), "How Law and Institutions Shape Financial Contracts: The Case of Bank Loans", Journal of Finance, 62(6): 2803-2834.

42. Rajan, R. G., and Zingales, L. (1995). What do we know about capital structure? Some evidence from international data. Journal of Finance, 50(5): 1421-1460.

43. Rodano, G., Serrano-Velarde, N. and E. Tarantino (2015). Lending Standards Over the Credit Cycle. Mimeo.

44. Samila, S. and O. Sorenson (2011). Venture Capital, Entrepreneurship, and Economic Growth. The Review of Economics and Statistics 93(1): 338-349.

45. Shvets, J. (2012). Judicial Institutions and Firms' External Finance: Evidence from Russia, Journal of Law, Economics, and organization doi:10.1093/jleo/ews006.

46. Visaria, S. (2009). Legal reform and loan repayment: The microeconomic impact of debt recovery tribunals in India. American Economic Journal: Applied Economics, 1(3): 59-81. 


\title{
BANCO DE ESPAÑA PUBLICATIONS
}

\author{
WORKING PAPERS
}

1511 PATRICIA GÓMEZ-GONZÁLEZ: Financial innovation in sovereign borrowing and public provision of liquidity.

1512 MIGUEL GARCÍA-POSADA and MARCOS MARCHETTI: The bank lending channel of unconventional monetary policy: the impact of the VLTROs on credit supply in Spain.

1513 JUAN DE LUCIO, RAÚL MÍNGUEZ, ASIER MINONDO and FRANCISCO REQUENA: Networks and the dynamics of firms' export portfolio.

1514 ALFREDO IBÁÑEZ: Default near-the-default-point: the value of and the distance to default.

1515 IVÁN KATARYNIUK and JAVIER VALLÉS: Fiscal consolidation after the Great Recession: the role of composition.

1516 PABLO HERNÁNDEZ DE COS and ENRIQUE MORAL-BENITO: On the predictability of narrative fiscal adjustments.

1517 GALO NUÑO and CARLOS THOMAS: Monetary policy and sovereign debt vulnerability.

1518 CRISTIANA BELU MANESCU and GALO NUÑO: Quantitative effects of the shale oil revolution.

1519 YAEL V. HOCHBERG, CARLOS J. SERRANO and ROSEMARIE H. ZIEDONIS: Patent collateral, investor commitment and the market for venture lending.

1520 TRINO-MANUEL ÑIGUEZ, IVAN PAYA, DAVID PEEL and JAVIER PEROTE: Higher-order risk preferences, constant relative risk aversion and the optimal portfolio allocation.

1521 LILIANA ROJAS-SUÁREZ and JOSÉ MARÍA SERENA: Changes in funding patterns by Latin American banking systems: how large? how risky?

1522 JUAN F. JIMENO: Long-lasting consequences of the European crisis.

1523 MAXIMO CAMACHO, DANILO LEIVA-LEON and GABRIEL PEREZ-QUIROS: Country shocks, monetary policy expectations and ECB decisions. A dynamic non-linear approach.

1524 JOSÉ MARÍA SERENA GARRALDA and GARIMA VASISHTHA: What drives bank-intermediated trade finance? Evidence from cross-country analysis.

1525 GABRIELE FIORENTINI, ALESSANDRO GALESI and ENRIQUE SENTANA: Fast ML estimation of dynamic bifactor models: an application to European inflation.

1526 YUNUS AKSOY and HENRIQUE S. BASSO: Securitization and asset prices.

1527 MARÍA DOLORES GADEA, ANA GÓMEZ-LOSCOS and GABRIEL PEREZ-QUIROS: The Great Moderation in historical perspective. Is it that great?

1528 YUNUS AKSOY, HENRIQUE S. BASSO, RON P. SMITH and TOBIAS GRASL: Demographic structure and macroeconomic trends.

1529 JOSÉ MARÍA CASADO, CRISTINA FERNÁNDEZ and JUAN F. JIMENO: Worker flows in the European Union during the Great Recession.

1530 CRISTINA FERNÁNDEZ and PILAR GARCÍA PEREA: The impact of the euro on euro area GDP per capita.

1531 IRMA ALONSO ÁLVAREZ: Institutional drivers of capital flows.

1532 PAUL EHLING, MICHAEL GALLMEYER, CHRISTIAN HEYERDAHL-LARSEN and PHILIPP ILLEDITSCH: Disagreement about inflation and the yield curve.

1533 GALO NUÑO and BENJAMIN MOLL: Controlling a distribution of heterogeneous agents.

1534 TITO BOERI and JUAN F. JIMENO: The unbearable divergence of unemployment in Europe.

1535 OLYMPIA BOVER: Measuring expectations from household surveys: new results on subjective probabilities of future house prices.

1536 CRISTINA FERNÁNDEZ, AITOR LACUESTA, JOSÉ MANUEL MONTERO and ALBERTO URTASUN: Heterogeneity of markups at the firm level and changes during the great recession: the case of Spain.

1537 MIGUEL SARMIENTO and JORGE E. GALÁN: The influence of risk-taking on bank efficiency: evidence from Colombia.

1538 ISABEL ARGIMÓN, MICHEL DIETSCH and ÁNGEL ESTRADA: Prudential filters, portfolio composition and capital ratios in European banks.

1539 MARIA M. CAMPOS, DOMENICO DEPALO, EVANGELIA PAPAPETROU, JAVIER J. PÉREZ and ROBERTO RAMOS: Understanding the public sector pay gap.

1540 ÓSCAR ARCE, SAMUEL HURTADO and CARLOS THOMAS: Policy spillovers and synergies in a monetary union.

1601 CHRISTIAN CASTRO, ÁNGEL ESTRADA and JORGE MARTÍNEZ: The countercyclical capital buffer in Spain: an analysis of key guiding indicators. 
1602 TRINO-MANUEL ÑÍGUEZ and JAVIER PEROTE: Multivariate moments expansion density: application of the dynamic equicorrelation model.

1603 ALBERTO FUERTES and JOSÉ MARÍA SERENA: How firms borrow in international bond markets: securities regulation and market segmentation.

1604 ENRIQUE ALBEROLA, IVÁN KATARYNIUK, ÁNGEL MELGUIZO and RENÉ OROZCO: Fiscal policy and the cycle in Latin America: the role of financing conditions and fiscal rules.

1605 ANA LAMO, ENRIQUE MORAL-BENITO and JAVIER J. PÉREZ: Does slack influence public and private labour market interactions?

1606 FRUCTUOSO BORRALLO, IGNACIO HERNANDO and JAVIER VALLÉS: The effects of US unconventional monetary policies in Latin America.

1607 VINCENZO MERELLA and DANIEL SANTABÁRBARA: Do the rich (really) consume higher-quality goods? Evidence from international trade data.

1608 CARMEN BROTO and MATÍAS LAMAS: Measuring market liquidity in US fixed income markets: a new synthetic indicator.

1609 MANUEL GARCÍA-SANTANA, ENRIQUE MORAL-BENITO, JOSEP PIJOAN-MAS and ROBERTO RAMOS: Growing like Spain: 1995-2007.

1610 MIGUEL GARCÍA-POSADA and RAQUEL VEGAS: Las reformas de la Ley Concursal durante la Gran Recesión.

1611 LUNA AZAHARA ROMO GONZÁLEZ: The drivers of European banks' US dollar debt issuance: opportunistic funding in times of crisis?

1612 CELESTINO GIRÓN, MARTA MORANO, ENRIQUE M. QUILIS, DANIEL SANTABÁRBARA and CARLOS TORREGROSA: Modelling interest payments for macroeconomic assessment.

1613 ENRIQUE MORAL-BENITO: Growing by learning: firm-level evidence on the size-productivity nexus.

1614 JAIME MARTÍNEZ-MARTÍN: Breaking down world trade elasticities: a panel ECM approach.

1615 ALESSANDRO GALESI and OMAR RACHEDI: Structural transformation, services deepening, and the transmission of monetary policy.

1616 BING XU, ADRIAN VAN RIXTEL and HONGLIN WANG: Do banks extract informational rents through collateral?

1617 MIHÁLY TAMÁS BORSI: Credit contractions and unemployment.

1618 MIHÁLY TAMÁS BORSI: Fiscal multipliers across the credit cycle.

1619 GABRIELE FIORENTINI, ALESSANDRO GALESI and ENRIQUE SENTANA: A spectral EM algorithm for dynamic factor models.

1620 FRANCISCO MARTÍ and JAVIER J. PÉREZ: Spanish public finances through the financial crisis.

1621 ADRIAN VAN RIXTEL, LUNA ROMO GONZÁLEZ and JING YANG: The determinants of long-term debt issuance by European banks: evidence of two crises.

1622 JAVIER ANDRÉS, ÓSCAR ARCE and CARLOS THOMAS: When fiscal consolidation meets private deleveraging.

1623 CARLOS SANZ: The effect of electoral systems on voter turnout: evidence from a natural experiment.

1624 GALO NUÑO and CARLOS THOMAS: Optimal monetary policy with heterogeneous agents.

1625 MARÍA DOLORES GADEA, ANA GÓMEZ-LOSCOS and ANTONIO MONTAÑÉS: Oil price and economic growth: a long story?

1626 PAUL DE GRAUWE and EDDIE GERBA: Stock market cycles and supply side dynamics: two worlds, one vision?

1627 RICARDO GIMENO and EVA ORTEGA: The evolution of inflation expectations in euro area markets.

1628 SUSANA PÁRRAGA RODRÍGUEZ: The dynamic effect of public expenditure shocks in the United States.

1629 SUSANA PÁRRAGA RODRÍGUEZ: The aggregate effects of government incometransfer shocks - EU evidence.

1630 JUAN S. MORA-SANGUINETTI, MARTA MARTÍNEZ-MATUTE and MIGUEL GARCÍA-POSADA: Credit, crisis and contract enforcement: evidence from the Spanish loan market.

BANCODEESPAÑA

Eurosistema
Unidad de Servicios Auxiliares

Alcalá, 48 - 28014 Madrid

E-mail: publicaciones@bde.es www.bde.es 